\title{
SONGGOLANGIT FM RADIO CONVERGENCE STRATEGY IN THE MIDDLE OF THE BROADCASTING INDUSTRY COMPETITION IN PONOROGO
}

\author{
Imasnyti Ciptanti Devi \\ Institut Agama Islam Negeri (IAIN) Ponorogo \\ Jl.Puspita Jaya, Jenangan, Ponorogo \\ E-mail : Imasnyti16@gmail.com
}

Abstract: Radio Songgolangit FM Ponorogo which is considered to have implemented the practice of media convergence. In the current era of media convergence, radio, which is considered a traditional media, must survive in the midst of increasingly fierce competition in the broadcasting industry to expand its audience and receive advertisements. This research is a descriptive study with a qualitative approach to describe the convergence strategy of Songgolangit FM radio in the midst of the competition in the broadcasting industry in Ponorogo. The data collection technique was carried out by using observation, interviews, and documentation owned by Radio Songgolangit FM then describing the subject under study. Based on the results of the analysis, it can be concluded that the convergence strategy of Songgolangit FM radio uses 3M, namely multimedia, multichannel, and multiplatform. Where information is presented in various formats ranging from photos, video, text, and audio. Meanwhile, all information is not only conveyed via broadcast radio but uploaded via social media and can be accessed through the respective audience devices. The implications of the convergence practice of Songgolangit radio are divided into social, cultural and economic implications. So, with the impact, Songgolangit FM radio can take advantage of the convergence era so that it can survive in the midst of intense competition in the broadcasting industry, especially in Ponorogo.

\section{Keywords: Convergence, Radio, Broadcasting}

\section{INTRODUCTION}

In the current era of globalization, technological developments have brought progress in various fields, such as information and entertainment needs for society. The rapid advancement of technology has also given birth to a new media called the internet. This new media is currently the fulfillment of information and entertainment needed by the community. Various information is easily enjoyed which then describes itself as new media. Broadcast media, which has the function of providing information and entertainment, feels threatened by technological developments and the emergence of new media. It also triggers intense competition between a media to grab their position. 
The role of radio as a traditional broadcasting medium must be able to lead to electronic media with modern technology so that it can continue to function in accordance with the needs of society, starting from communication, education, information and entertainment. Radio, which is one of the broadcast media which has familiar characteristics and is cheap, is still in demand by the public. You can even listen to the radio flexibly, which means you can enjoy it while doing other activities without disturbing you. Therefore, radio is still around despite the arrival of new media or the internet. ${ }^{1}$

The emergence of the internet also makes broadcasting media continue to compete to expand its audience and get advertisements, where advertising is a source of revenue for the broadcast media. The number of advertisers who prefer to install on the internet, website, or social media makes various media compete with each other to improve the quality of their production in order to get the maximum profit. Hence, media convergence emerged.

In the current era of media convergence, people can use one device for two activities at a time, such as accessing the internet and listening to the radio. In addition, the presence of the internet is suspected of bringing changes in a person's lifestyle. Media convergence is carried out not merely by following technological developments. The mutual integration of conventional mass media with online media allows for expansion of coverage at any scale. Starting from publication and interaction with listeners, of course, will have differences. After the emergence of new media, radio can change from interactive telephone to interaction via social media. As a result, the mass media become stronger and more diverse in presenting their creative products to the public. However, it must also compete to maintain the loyalty of its audiences. Thus, the mass media must keep up with advances in information technology by combining conventional media with new media. Broadcasting media, especially radio, currently have many access to new media to expand the audience market. ${ }^{2}$

The rapid development of private and community radio in Ponorogo causes anxiety because the level of competition or competition in the broadcasting industry is also increasing. On the other hand, as a business entity, private radio faces challenges that are not easy. Private radio like other industries requires more resources that support the survival of the media. With limited media resources, it is certain that the life of private radio will be threatened. Private radio, get funding by relying on the potential for advertising.

\footnotetext{
${ }^{1}$ Asep Syamsul M. Romli, Dasar-Dasar Siaran Radio : Basic Announcing (Bandung: Nuansa, 2009), 20

${ }^{2}$ Diyah Hayu Rahmitasari, Manajemen Media di Indonesia (Jakarta: Yayasan Pustaka Obor Indonesia, 2017), 231.
} 
So that almost all private radio has a responsibility fully answer to sponsors or advertisers to play their ads because they have already paid advertising rates. More precisely, private radio is a commercial broadcasting institution for the continuity of its broadcasts. So, if, radio does not take advantage of the new media in the current convergence of media, they will not be able to offer advertising in a further reach.

In the midst of the many radios in Ponorogo, Songgolangit FM Ponorogo radio is one radio that utilizes various media in the current convergence era. To keep up with the development of existing technology and information, new media or online media are used by Radio Songgolangit to further disseminate its information to the public. Not only that, but the media is also used to expand listeners to advertisers on Radio Songgolangit FM to make it more diverse.

Radio Songgolangit FM Ponorogo is one of the private radio stations in Ponorogo which has been established 13 years ago. ${ }^{3}$ During its journey, many changes have been made such as completely changing the broadcast format to news radio. On the 99.2 FM frequency, Radio Songgolangit is ready to provide information as well as solutions from the Ponorogo area and its surroundings. And now Radio Songgolangit has prepared itself to face the era of media convergence so that it can maintain its audience in the midst of intense competition in the broadcasting industry, especially in Ponorogo.

Radio is fleeting broadcast media, in the sense that what the announcer has conveyed cannot be repeated. Therefore, so that listeners can still receive information that has been conveyed by broadcasters, in 2010, Radio Songgolangit has used Facebook social media with the Songgolangit Pride Ponorogo account and connected with the Songgolangit FM Radio Fanspage to spread the information. Because, at that time the new media had penetrated the wider community, so Radio Songgolangit also made use of online media so that it could continue to be accepted by the public. From Facebook, listeners can reread the information that has been conveyed by the broadcaster. In 2016, along with the emergence of new online media, Radio Songgolangit also did not want to lose, by switching to Instagram @ radio $\neg$ ᄀ_songgolangit without leaving Facebook. By having the same function, namely disseminating information that is owned, and showing the activities of Radio Songgolangit at that time. With the internet which is owned by radio, it can expand the broadcast coverage. So that makes radio perform media convergence. It doesn't stop there, in 2018, Radio Songgolangit has started using streaming or live broadcasts by accessing online radiobox on Google to reach a wider audience to international audiences. ${ }^{4}$

In early 2019, Radio Songgolangit also created a website www.radiosonggolangit.com, so that all information about radio can be accessed 
easily on the owned website page. In this millennial era, his party wants to further improve the quality of streaming, to make it easier for listeners, his party collaborates with IT Madiun to create a web about streaming that is incorporated in the Online Radio Box website. However, over time, because the Online Radio Box site was deemed not easy to use because it had to enter the Google page first, Radio Songgolangit collaborated with Darrusalam Gontor University by creating a streaming application on the play store with the name Radio Songgolangit Ponorogo. This aims to make it easier for listeners to be able to download directly through the Playstore without having to enter a google search.

Songgolangit FM radio, included in one of the radios known by the people of Ponorogo. There is even a group on WhatsApp social media whose members are loyal listeners of Radio Songgolangit and are still active today. The convergence of media that has been carried out by Radio Songgolangit FM, can bring about many changes, such as communication that initially goes one way to two directions. In addition, the application for streaming, it can expand the reach of listeners outside the city and even abroad. The convergence that has been carried out offers everyone the opportunity to become a mass communicator. ${ }^{5}$ That way, of course, the interest in Radio Songgolangit FM can increase. Not only that, but the use of the internet also benefits the marketer to find more advertisers, in order to get bigger profits. Because nowadays, many advertisers are more interested in posting their products on social media, with the aim of attracting consumer interest in their products. So that Radio Songgolangit used this, by being able to install products from advertisers through their social media such as Facebook, Fanspage, and Instagram.

In this era of media convergence, Radio Songgolangit FM certainly has its own strategy in order to maintain its position as a broadcast media that is in demand and meet needs in various fields such as technology, communication, information, and entertainment in order to survive in the midst of intense industrial competition.

This makes the writer interested in examining how the convergence strategy of Songgolangit FM Radio and how the impact of media convergence on Radio Songgolangit FM Ponorogo amidst the broadcast industry competition in Ponorogo today.

The formulation of the problem is based on the background of the above problems, this paper focuses on the convergence strategy of Songgolangit FM Radio in the competition in the broadcasting industry in Ponorogo. If asked in the form of questions, the sub-problems in this study can be formulated as follows: (1) How is the Convergence of Songgolangit FM Radio in the Middle of the Competition in the Broadcasting Industry in Ponorogo. (2) What are the implications of the convergence practice of Songgolangit FM radio in Ponorogo?

This research uses a descriptive type of research with a qualitative approach. This type of research is descriptive research, namely research that is intended to

${ }^{5}$ Rahmitasari, Manajemen Media di Indonesia, 231. 
describe existing problem solving based on data such as presenting data, analyzing, and interpreting. ${ }^{6}$

The qualitative approach aims to gain a general understanding of social reality from the perspective of the participants. This understanding is not determined in advance but is obtained after analyzing the social realities which are the focus of the research and then a conclusion is drawn in the form of a general understanding of these facts. The researcher used a qualitative descriptive approach because the researcher wanted to describe the results of the study using written words and describe the results of the interview from the research object. ${ }^{7}$ In this study, the researcher describes the media convergence strategy on Songgolangit FM Radio in competition in the broadcasting industry.

\section{Mass Media Strategy in Media Convergence.}

Mass media is part of mass communication which plays an important position in accelerating the delivery of the latest information to the public. The mass media as a channel of information has a role to monitor or seek information, develop selfconcepts, as a facility in social relations, and as part of routine life or ritualization. ${ }^{8}$ The development of the mass media industry took place rapidly and caused the mass media to no longer be the ideal institution for delivering accurate and balanced information. Mass media is also transformed into an economic capitalization institution for media entrepreneurs.

To survive in the competition, mass media companies need to pay attention to the existence of marketing steps, namely: ${ }^{9}$ (a) audience segmentation is carried out by dividing the audience into several groups that have different characteristics, behaviors, and needs. (b) Audience targeting, selection of several market segments. (c) Audience positioning, carried out by competing products and creating a more detailed marketing mix.

Media convergence is the merging or integration of existing media to be used and directed into a single destination. Unification of various services and communication and information technology via the internet. Expression in the popular mass media makes it easier to understand convergence for consumers in general not only to the activities of the computing, telecommunications, and broadcasting industries to enter the future market. Convergence is also understood as the unification of $4 \mathrm{C}$ services, namely communication, computer, contents, and community. ${ }^{10}$

\footnotetext{
${ }^{6}$ C. Suprapti Dwi Takariani, "Eksistensi Media Lokal di Era Konvergensi", Ilmu Komunikasi (2013), 27-28.

${ }^{7}$ Cholid Narbuko dan Abu Achmadi, Metodologi Peneltiain (Jakarta: Bumi Aksara, 2015), 44.

${ }^{8}$ Ibid.

${ }^{9}$ Supadiyanto, Pengantar Jurnalisme Konvergentif, 187.

${ }^{10}$ Danrivanto Budhijanto, Hukum Telekomunikasi, Penyiaran, dan Teknologi Informasi : Regulasi dan
} 
Since the 1990s, the term convergence is often used in the development of digital technology, the integration of different texts, numbers, images, and sounds in the media. In 1970, the word convergence was used to refer to many things in its content, as an interaction of computers and telecommunications equipment. So that there was an inaccurate term, "Compunications", which is the description that appeared earlier. ${ }^{11}$ Entering 2000, the development of Information technology (IT) began to spread to Indonesia so that the IT trend emerged. TI has presented a new media in disseminating information, namely digital media. ${ }^{12}$ Media convergence that carries the concept of unifying various information services in one information device makes information develop very quickly and without boundaries that can prevent individuals from being exposed to the information flow (exposure). Conventional media, it is not impossible to die in the future, when everyone flock to choose digital media that is more efficient to obtain information, automatically all kinds of advertising will also switch to digital media because of the demands of these consumers.

Convergence changes the relationship between technology, industry, markets, lifestyles, and audiences. Convergence provides new opportunities for the public to expand media access options according to their tastes. From the economic side of the media, convergence means new professional opportunities in the world of the communications industry.

\section{Strategies of Radio Media Convergence}

The convergence of the media which demands a change in the system of mass media companies provides a way to adapt. Namely by using a converged media strategy. The power of content in the mass media must be strengthened by 3M's strategy in growing the business. $3 \mathrm{M}$ is at the same time an element of Media convergence. This strategy affects the process of creating a product or content in the mass media and on the audience. 3M includes: (a) Multimedia. A medium creates and provides information in various formats of text, photos, animation, audio, or video. With this strengthening of multimedia, the audience will be more interested and the need for information will be fulfilled. (b) Multichannel. Using various methods and channels of information distribution, both physical and digital. For example, in addition to listening to radio broadcasts to get information, the public can access the internet to get the same information. This is supported by a large number of media to consume information. (c) Multiplatform. Using various devices to access information, such as

Konvergensi, (Bandung: Refika Aditama, 2013), 269.

${ }^{11}$ Ibid., 270.

12 Deby Rizky Susilo, Pengaruh Konvergensi Media Massa Terhadap Kepuasan Pelanggan Lampungpost.id (Lampung: Universitas Lampung, 2019), 27-28. 
smartphones, television, Youtube, Facebook, and so on. So that this multiplatform has flexibility for the public to choose the device it has to access information. ${ }^{13}$

There are 5 Dimensions of Media Convergence, including (a) Ownership Convergence. This convergence refers to the ownership of large media companies over several types of media. For example, a media company that is the parent of print media, online media, and broadcast media. (b) Tactical convergence. This convergence is a form of trick or a way of working together by carrying out crosspromotion and exchange of information obtained from converging or cooperating media. For example, special coverage of a newspaper is promoted on television or vice versa, a television special program is advertised in newspapers and online. (c) Structural convergence. This convergence requires a redesign of the division of labor and organizational structuring in each media that has become part of the convergence. The organizational structure and job descriptions that have implemented convergence are reorganized and adjusted to meet convergence needs. (d) Information gathering convergence. This type of convergence occurs when journalists who are referred to as backpack journalists or journalists who have the skills to work in more than one type of media are expected to be able to collect data, process, and present data on various platforms. In other words, journalists are required to report the results of their coverage on a different platform. Can be to print platforms, television or online. (e) Storytelling convergence. This form of convergence requires journalists' skills in packaging news according to the relevant media market segment and is accompanied by photos, videos, and graphics. ${ }^{14}$

\section{Media Convergence Theory}

Jenkins' research has focused on the concept of "media convergence", arguing that simple technology focuses on how individuals in contemporary cultures themselves enter and combine many different media sources offering a much richer understanding of the relationships between different forms of media. ${ }^{15}$

According to Jenkins, five processes change the produced and consumed media, namely: (a) Economic convergence occurs when a company controls several products or services in the same industry. (b) Social convergence It occurs when a person accesses conventional media online and at the same time communicates online in the form of exchanging text messages with friends as well as listening to music. (c) Technology convergence the unification of various technologies, namely when one or more different media is transformed into digital form. (d) Cultural convergence. Occurring when stories flow to various forms of media is one component. For example, a novel that became a television series such as Band of

13 Deby Rizky Susilo, Pengaruh Konvergensi Media Massa Terhadap Kepuasan Pelanggan Lampungpost.id (Lampung: Universitas Lampung, 2019), 27-28.

${ }^{14}$ https://id.wikipedia.org/wiki/Konvergensi_media diakses pada 5 Januari 14.25 WIB.

${ }^{15}$ https://id.wikipedia.org/wiki/Henry_Jenkins diakses pada 5 Januari 202013.36 WIB. 
Brother. (e) Global convergence. The process of influencing geographically distant cultures in other cultures. ${ }^{16}$

\section{Radio Convergence}

\section{Definition and a Brief History of Radio}

Radio is a technology used for transmitting signals through modulation and electromagnetic radiation (electromagnetic waves). These waves pass and propagate through the air and can also propagate through space that is empty of air because these waves do not require a transport medium (such as air molecules). ${ }^{17}$

The history of radio begins with the discoveries in the field of physics in the XIX century AD. There are some names that can be said to be the perpetrators of the history of radio. Those who directly or indirectly became the "founding fathers" or founding fathers or inventors of this radio include Michael Faraday, James Clerk Maxwell, Heinrich Hertz, Gaglieso Marconi, Nikola Tesla, David Sarnoff, Lee De Forest, Frank Conrad, and Edwin Howard Armstrong. ${ }^{18}$

The history of the invention of the radio began in England and the United States. Donald Mc. Nicol in his book Radio's Conquest of Space states that the conquest of space by radio began in 1802 by Dane, namely the discovery of a message over a short distance using a simple tool in the form of an electric wire. The next discovery was made by three young intellectuals, namely James Maxwell, who was nicknamed the Scientific father of wireless because he managed to find formulas that allegedly created electromagnetic waves, namely waves used by radio and television that propagate at the speed of light.

It was only in 1912 that Edwin Howard Armstrong invented a radio wave amplifier called the Radio amplifier. This tool works by capturing electromagnetic signals from radio transmissions and giving back signals from the tube. The sound that is captured is also much stronger so that it can be heard directly without using earphones. This invention later became very important in radio communication systems because it was much more efficient than previous tools. However, the patent rights for the amplifier fell to Dr. Lee De Forest. ${ }^{19}$

The use of radio as a tool or mass communication medium was initially introduced by David Sarnoff in 1915. Furthermore, Le De Forrest through his radio broadcast experiment, which had broadcast the United States presidential election campaign in 1916, so that was known as a pioneer of radio broadcasting. Initially, the signal in radio broadcasts was transmitted via continuous data waves either through amplitude modulation (AM) or frequency modulation (FM). This method

\footnotetext{
${ }^{16}$ Ibid.

${ }^{17}$ Asep Syamsul M. Romli, Basic Announcing : Dasar-Dasar Siaran Radio (Bandung: Nuansa, 2009), 12.

${ }^{18}$ Ibid.,12-16.

${ }^{19}$ Ibid.
} 
of sending signals is called analog. Furthermore, along with the development of technology the internet was discovered, and digital signals changed the way radio signals were transmitted. ${ }^{20}$

Until the Early Independence of the Republic of Indonesia, radio broadcasts were still controlled by Japan until when Bung Karno and Bung Hatta proclaimed Indonesia's independence this news could not be broadcast live via broadcast radio. However, in the end, the news of the proclamation of Indonesia's independence could be broadcast on the air via a radio broadcast station called "Radio Indonesia Merdeka". The first radio that was established and belonged to Indonesia after independence was Radio Republik Indonesia, which was founded on September 11, 1945. Until the end of 1966, RRI was the only radio broadcast in Indonesia controlled and owned by the government. ${ }^{21}$

During the early days of the New Order, around 1966-1968, private radio broadcasts began to grow in Indonesia, whose existence followed various regulations set by the Government. The legal umbrella for the existence of Indonesian national private broadcast radio refers to the Government Regulation of the Republic of Indonesia Number 55 of 1970 concerning Non-Government Broadcasting Radio. Quoted from the PRSSNI radio page, it is stated that the PP regulates the functions, rights, obligations, and responsibilities of radio broadcasts, terms of operation, licensing, and supervision. 22

On 16-17 December 1974, the First Congress of Private Broadcasting Radio throughout Indonesia was held in Jakarta which was attended by representatives of 173 private radio broadcasts from 34 cities in 12 provinces in Indonesia. The congress resulted in a decision to form an organization for private radio broadcasts in Indonesia called the Indonesian Private Commercial Radio Broadcast Association or PRSSNI. Then in 1983 the IV PRSSNI National Conference was held in Bandung and resulted in a decision to replace the term "Commerce" with "National". So that PRSSNI became the Indonesian National Private Broadcast Radio Association. ${ }^{23}$

\section{Old Radio and New Radio}

Broadcast radio is a form of mass communication. Through radio broadcast, a communication that will be conveyed by the communicator to a large audience can take place in a short time and the communicant will receive communication simultaneously even though in different and scattered places.

Radio is seen as the fifth state after the executive (government, legislative (parliament), judiciary (judiciary), and the press or newspapers. This is partly

\footnotetext{
${ }^{20}$ Ardianto Elvinaro, Komunikasi Massa (Bandung: Simbiosa Rekatama Media, 1986), 117-119.

${ }^{21}$ Ibid.

${ }^{22}$ Herley Prayuda, Radio Suatu Pengantar Untuk Wacana dan Praktik Penyiaran (Jakarta: Bayu Media, 2000), 23-25.

${ }^{23} \mathrm{Ibid}$.
} 
because radio has direct power, does not recognize distances and obstacles, and has its charm. ${ }^{24}$

By utilizing new media, this is a step to keep radio upright, can become a new medium to increase the reach of radio listeners who are not only focused on onair broadcasts (on air) but also digital content. New media is constantly changing and evolving over time. One of the fast developments of new media was at the time of digitization. The emergence of the internet has played a major role in the digitalization relationship with new media. The internet is a medium that is able to converge all the characteristics of the media from the previous forms, which focus on the communication process. When it comes to the development of new media, the emergence of the internet has played a role in the birth of online media which was booming. ${ }^{25}$

The internet is not a competitor to the radio, but radio can use the internet to turn other forms into streaming radio, or streaming video and develop content in various media.

\section{Challenges of Radio}

The phenomenon of the internet skyrocketing and the era of media convergence can be said to be one of the popular cultures among Indonesian people, because people are now starting to rely on the internet as one of the main sources of information reception, shifting the position of radio. Radio, which is a conventional mass media, is considered far behind compared to other media and along with technological developments, radio has had various changes. Conventional media such as radio turned into a convergence medium. This is what makes radio have the challenge to compete with other mass media. Meanwhile, the audience or the public is a factor in changing the challenges faced by radio because the audience will choose the radio that suits their needs. ${ }^{26}$

On the other hand, the current development of the internet is also a big challenge for the radio. Many people choose to use the internet because it is considered easier to access anything, not only audio but also audiovisual. Another radio challenge, there is also the issue of cost, where many radios have good programs but, because there is no cost, the programs are not realized. Not only that, competition with other radios that utilize internet networks or what is known as streaming radio is also a challenge for radio. Not enough here, the difficulty in getting advertisers were also complained of by several radios. Many advertisers prefer to post on other conventional media such as television and newspapers so

\footnotetext{
${ }^{24}$ Romli, Basic Announcing: Dasar-Dasar Siaran Radio, 17.

${ }_{25}$ Septiawan Santana Kurnia, Jurnalisme Kontemporer (Jakarta: Yayasan Obor Indonesia, 2005), 16.

${ }^{26}$ https://meisyanc.wordpress.com/2016/06/06/tantangan-radio-di-indonesia/, diakses pada 21 Februari 2020, pukul 16.34 WIB.
} 
that their products can be seen. So, the radio must really be able to take advantage of the convergence era with the use of internet technology in order to reach all listeners and the market. ${ }^{27}$

Seeing the many challenges of radio today, it is necessary to have a strategy to be able to continue to maintain the existence of radio as mass media and public communication media amidst media convergence. The strategy that needs to be done also comes from internal factors, how a commitment and good cooperation within the team to make radio programs greatly affect radio performance and quality. Managing the upcoming radio will be a bigger challenge for the radio industry in Indonesia. There needs to be creative innovation in the midst of media convergence.

\section{Songgolangit FM Radio Convergence Strategy in the Middle of Competition in the Broadcasting Industry in Ponorogo}

Radio Songgolangit before implementing media convergence, social media was only owned by Facebook and was limited to being used for social media without reporting or conveying broadcast material information. In fact, advertisers are only conveyed via manual broadcast radio, not on social media so that there is no media opinion. However, with the application of convergence to date, all information can be conveyed through social media, and advertisers or clients can choose to post their products on social media or via manual radio. So, there is also income from this convergence. In fact, there is an increase in income of up to 50 percent.

To achieve success in this convergence process, a broadcast media must be able to implement $3 \mathrm{M}$, which is a media convergence strategy, to implement it well, namely multimedia, multichannel, and multiplatform. The three media convergence strategies must be interrelated, not just implementing one of them. This is a unit that must be carried out simultaneously. Likewise with Songgolangit FM Radio can implement a media convergence strategy to expand its audience so that it can continue to compete in the current tightness of the broadcasting industry in Ponorogo.

The convergence of Songgolangit FM Radio amidst the competition in the broadcasting industry in Ponorogo was carried out in several steps according to the media convergence strategy, namely Multimedia, Multichannel, and Multiplatform. ${ }^{28}$ First, Multimedia. A broadcast media that wants to implement media convergence to survive must be able to create and present information in various formats ranging from text, photos, audio, video, and so on. The use of digital technology allows the information provided by the mass media to change and vary

${ }^{27}$ C. Suprapti Dwi Takariani, "Eksistensi Media Lokal di Era Konvergensi", Ilmu Komunikasi (2013), 27-28.

28 Deby Rizky Susilo, Pengaruh Konvergensi Media Massa Terhadap Kepuasan Pelanggan Lampungpost.id (Lampung: Universitas Lampung, 2019), 27-28. 
according to distribution or dissemination. Multimedia is very possible if the content produced is present in digital form. Media convergence refers to the ability to display multiple formats via a single medium..$^{29}$

In implementing this convergence, Radio Songgolangit FM always strives to provide information that has a positive impact on the public. Information in the form of photos, videos, audio, and writings is packaged in such a way that it can be conveyed to the public. That way all news can be accounted for. Even the application of this multimedia can increase netizen confidence in the information conveyed.

Based on interviews conducted with the Songgolangit FM Broadcasting Responsibility and Gatekeeper, it is known that conveying information is not only in the form of audio which is only broadcast via manual radio but also uses various formats. Although not the whole, only photos, text, and videos. In audio form, when broadcasters convey information via radio manually. Meanwhile, photos, videos, and texts are conveyed through social media owned by Radio Songgolangit FM. The use of these various formats makes it easier for broadcasters to convey information to audiences. So that the information conveyed by this announcer can be proof that the news is true when a photo or video is included. This is because readers or audiences can immediately see, read, and even hear the information conveyed themselves.

Not only for broadcasters, but the application of convergence with multimedia also makes it easier for marketing to find advertisers as one of the revenues of Songgolangit FM Radio. In the strategy of finding advertisers, convergence is needed to offer products that are owned.

Based on the results of interviews with the Songgolangit FM Radio Marketing Manager, it is known that to facilitate the application of this multimedia, marketing offers advertising in the form of text, photos, and videos. This got enthusiasm from advertisers. The offer is a package price for advertising. Where the advertising package already contains OnAir advertisements (spot and adlib), talk shows, and is uploaded on social media belonging to Radio Songgolangit FM. Advertisers prefer package prices because it includes promotions on social media. The application of multimedia here is that the advertiser sends his store photo or product photo from the advertiser. The photo was later translated by the broadcaster during the broadcast.

Changes in various formats were triggered by trends in multimedia generated by technology and communication via the internet. Thus, a multimedia strategy that presents various formats applied by Radio Songgolangit to achieve convergence can make broadcasting and marketing easier. Radio Songgolangit FM continues to present various formats so that it can continue to compete with other media.

${ }^{29}$ Aritasius Sugiya, Strategi Transformasi Konvergensi Media (Jakarta: Universitas Indonesia, 2012), 50 . 
Second, Multichannel Media convergence cannot be separated from the emergence of new media such as Facebook, Instagram, Youtube, Websites, and so on. Because according to its definition, media convergence is the merging of several media into one unit. In the application of media convergence using and maximizing various methods and channels of information distribution in physical and digital. For example, information obtained, apart from being broadcast, is also uploaded via social media. Thus, the audience will consume various information. ${ }^{30}$

Recently, social media or new media that are connected to the internet, make it easier for people to access information through various platforms. Multichannel allows audiences to have more media choices with diverse content. This is because today's audience cannot be separated from social media regardless of age. With the use of social media, it makes it easier for someone to access incoming information.

Based on interviews with the Songgolangit FM Broadcasting Responsibility and Gatekeeper, Radio Songgolangit also utilizes owned media starting from Facebook, Fanspage, Instagram, and Website. So that information that has been conveyed by broadcasters via radio manually, can also be accessed by listeners through their social media. This is because, radio is fleeting, what the announcer says can only be heard at that moment. So that listeners can still access the information conveyed at any time and provide feedback directly, one effort is also uploaded on other social media. That way, communication can go both ways, because of the provision of a comment column, where readers can immediately convey information at a moment's notice. Also, the purpose of uploading information that has been conveyed through social media is to provide evidence that the news that has been broadcast is true and can be accounted for.

For marketing, with this multichannel strategy, they can better help to advertise a product owned by their clients through social media so that it can be accessed by all people. Based on the results of interviews with the Songgolangit FM Radio Marketing Manager, that advertisers obtained also know from other advertisers whose products are uploaded on social media or broadcast via streaming radio. So, many advertisers choose price packages so that they can be uploaded via social media, Songgolangit FM Radio.

With this multichannel strategy, products owned by clients can be accessed by anyone and anywhere, not only in broadcast form but also through social media. The advantage of implementing this convergence is that it is easier because in the beginning the advertisements obtained were only read or broadcast via manual radio and only those who accessed the radio wave coverage area. With the offering of advertisements in the form of uploads on social media, there must be a price offered. That way, the profits that can be obtained from social media also increase for Radio Songgolangit's revenue. 
Third, Multiplatform Media convergence also appears with the existence of several devices to access information, namely multiplatform. Content in mass media can be produced and accessed from various tools and devices. Where the tools and devices must be able to access various kinds of multimedia. The tools or devices used are useful for producing various types of materials for accessing or producing content in mass media, especially radio. This multiplatform gives consumers the freedom to enjoy information products through various devices owned by the public. Starting from cellphones, PCs, laptops, and so on. ${ }^{31}$

Based on the results of interviews with the Songgolangit FM Broadcasting Responsibility and Gatekeeper, all news or information that is presented in various formats and uploaded to social media can be accessed on all devices owned by the audience. Not only that, but radio streaming can also be downloaded via Android audiences. Moreover, at this time the development of technology is also increasing rapidly. Ownership of gadgets is not only for teenagers but in all lines of society. So that information can be accessed by anyone and anywhere.

Meanwhile, based on the results of interviews with the Songgolangit FM Radio Marketing Manager, that the rapid development of technology and the emergence of new technologies make it easier for people to access advertised products. So that it is not only news information. Because all information or advertisements on Radio Songgolangit can all be accessed through the devices of each audience.

At present, we must implement multiplatform media convergence. It cannot be denied that people's life is now closely related to digitalization. The existing technology is also indiscriminate. So that the emergence of new technology makes it easier for the media industry, especially Radio Songgolangit FM, to convey information anytime, anyone, and anywhere.

\section{Implications of the Songgolangit FM Radio Convergence Strategy Amid the Competition in the Broadcasting Industry in Ponorogo}

The convergence of the media also has an impact on the news programs on Radio Songgolangit FM, where the radio crew must change their strategy to be able to apply the convergence. Strategies start from conveying information, which is not only conveyed manually but also through social media in different languages so that news can be accessed easily for the public. These impacts occur in all levels of society. Convergence provides new opportunities for the public to expand media access options according to their tastes. Meanwhile, the implications of the convergence practice of Songgolangit FM Radio are social implications, cultural implications, and economic implications. (1) Social Implications The presence of media convergence like this has a major effect on community socialization and is a factor in the changing patterns of community interaction. With the availability of media, it makes it easier 
for people to interact with each other. Although separated by distance, but with the help of the media, interactions can be carried out easily. The use of internetconnected media has been proven to be able to bridge human interaction, even from far to near. The lifestyle of fixated on technology is also felt by society. So that many people rely on information conveyed through social media rather than through radio broadcasts. In the results of interviews with local listeners of Radio Songgolangit FM, that the application of disseminating information in various formats provides evidence that the information that has been conveyed in audio or voice form via manual radio is true. So that listeners feel confident in the information. It doesn't stop there, the emergence of new media as a form of convergence also makes it easier for listeners to access news through social media. So, even though they are not listening to the radio, they can still access information that has been conveyed on social media and can comment directly. So that without realizing it, they also get information and spread information that is owned by listeners. The rapid development of technology also makes it easier for listeners to enjoy all forms of information conveyed by Radio Songgolangit with the listener's device. (2) Cultural Implications Merging several technologies into one has a positive impact which can introduce a culture to another culture. The introduction of these cultures is packaged in information then uploaded on social media or broadcast via streaming applications and delivered back not only to the local community but also on an international scale. People become aware of the culture of several regions and from around the world. thanks to the growing convergence of media, people will be more familiar with cultures from around the world without having to come to that place. Not only for local listeners, but the application of media convergence by Radio Songgolangit FM also has an impact on listeners who are abroad. Based on the results of an interview with one of the listeners in Malaysia, conveying information in the presence of a photo or video makes it easier for listeners to understand the news in depth. Radio can now bring people who are far away because initially it could only be heard for the local community, now it can be heard for the community on an international scale. So, listeners who are abroad can share information abroad. The streaming application that is owned by Radio Songgolangit, can easily be used by those in neighboring countries. (3) Economic Implications The convergence phenomenon has affected the economic aspects of society. With the existence of social media, it makes it easier for clients or advertisers to promote their products, thus increasing its benefits for advertisers and songgolangit radio revenue. By utilizing the social media application owned by Radio Songgolangit, advertisers can participate in promoting it. The use of social media in promoting products owned by advertisers is considered to be able to make it easier to find other targets. At present, every human being cannot be separated from playing social media. People themselves tend to use social media as a place to make and earn money. Those who do have the opportunity to advance the economy. Thanks to the convergence of the media in terms of making business easier, faster, and more efficient. If media 
companies and the public can make good use of current technological developments, benefits can be obtained. Economically, with changes in the culture of society caused by convergence, there will actually be great opportunities to use it to become a business field. In general, information technology convergence actually provides innumerable benefits to the wider community. It is undeniable that one of the revenues on the radio is from advertising. The current media convergence has made advertisers no longer hesitate to place advertisements in conventional media, especially radio. Because with affordable price quotes, advertisers' products can be easily accessed by consumers in just one click. From the results of an interview with a listener and advertiser on Radio Songgolangit, that offers can place advertisements by including photos or videos, and uploading them on social media really helps them to sell or introduce their products. So that the products owned by advertisers are not limited to broadcast on manual radio. And not only heard by local people, but can be accessed very easily by all people of all ages only through social media connected to the internet on their respective gadgets. The use of modern technology such as gadgets is believed to be able to help spread the products owned by one device to another. The use of media convergence to look for advertisements has become a symbiotic mutualism for marketers and advertisers themselves. Where marketing gets revenue from offering advertising through social media. Meanwhile, advertisers have the advantage that their products are better known to the wider community.

\section{CONCLUSION}

Based on the research in the thesis "Songgolangit Radio Convergence Strategy Amid the Competition in the Broadcasting Industry in Ponorogo", it can be concluded that:

1. Radio Songgolangit convergence strategy in the middle of broadcasting industry competition in Ponorogo with several steps, namely Multimedia, Multichannel, and Multiplatform. First, multimedia by presenting various formats such as photos, video, audio, and text to convey news and advertising information. Both multichannel, where all information that has been presented in various formats is not only conveyed via radio broadcasts but also uploaded on social media or via radio streaming. Although for information in the form of advertisements according to client requests. The third is multiplatform, information conveyed on social media or via radio streaming by Radio Songgolangit can be accessed by anyone, anywhere, anytime via gadgets, laptops, computers, or other audience devices.

2. The implications of the convergence practice on Radio Songgolangit FM are divided into three, namely social, cultural, and economic implications. First, the social implication, the convergence applied by Radio Songgolangit FM has an impact on the socialization of the community or its listeners and is a factor in the changing patterns of community interaction. Second, the 
cultural implications are the presence of convergence practices into changes in culture and people's lifestyles. The large number of media used by Songgolangit radio and some listeners are also abroad, making it easier for their audiences to get to know the cultures of other countries. Three economic implications, the convergence practice of Radio Songgolangit makes it easier for clients to further promote their products through social media owned by Songgolangit radio, this has an impact on increasing income for clients.

\section{REFERENCES}

Afrizal. Metode Penelitian Kualitatif. Jakarta: Rajawali Pers. 2014.

Basrowi. Memahami Penelitian Kualitatif. Jakarta: Rineka Cipta. 2008.

Budhijanto, Danrivanto. Hukum Telekomunikasi, Penyiaran, dan Teknologi Informasi: Regulasi dan Konvergensi, Bandung: Refika Aditama. 2013.

Ghony, M. Djunaidi dan Fauzan Almanshur. Metode Penelitian Kualitatif. Yogyakarta: Ar-Ruzz Media. 2012.

Hamidati, Anis. Komunikasi 2.0 Teoritisasi dan Implikasi. Yogyakarta: Mata Padi Pressindo. 2011.

https://id.wikipedia.org/wiki/Henry_Jenkins diakses pada 5 Januari 202013.36 WIB.

https://id.wikipedia.org/wiki/Konvergensi_media diakses pada 5 Januari 14.25 WIB.

https:/ /id.wikipedia.org/wiki/Media_baru diakses pada 4 Januari 202010.00 WIB. Hudaya, Asyar. Tinjauan Hukum Islam Terhadap Jasa Iklan di Perseroan Terbatas Radio Swara Ponorogo. Skripsi STAIN Ponorogo : Muamalah. 2016.

Mahmud. Metode Penelitian Pendidikan. Bandung: CV Pustaka Setia. 2011.

McQuail, Denis. Teori Komunikasi Massa suatu pengantar, terj. Agus Dharma dan Aminuddin Ram. Jakarta: Penerbit Erlangga. 1987.

Moleong, Lexy J. Metodologi Penelitian Kualitatif,. Bandung: Remaja Rosdakarya. 2017. Morrisan. Manajemen Media Penyiaran: Strategi Meneglola Radio E Televisi. Jakarta: Kencana. 2011.

Narbuko, Cholid dan Abu Achmadi. Metodologi Peneltiain. Jakarta: Bumi Aksara. 2015.

Nugrahani, Farida. Metode Penelitian Kualitatif dalam Penelitian Pendidikan Bahasa. Surakarta. 2014.

Nurullah, Bayu. Konvergensi Media Radio Republik Indonesia (RRI) di Bandung. Skripsi Universitas Pasundan: Ilmu Komunikasi. 2019.

Raco, J. R. Metode Penelitian Kualitatif: Jenis, Karakteristik dan Keunggulannya. Jakarta: PT Grasindo. 2010.

Rahmitasari, Diyah Ayu. Manajemen Media di Indonesia. Jakarta: Yayasan Pustaka Obor Indonesia. 2017.

Rahmitasari, Diyah Hayu. Manajemen Media di Indonesia. Jakarta: Yayasan Pustaka Obor Indonesia. 2017. 
Romli, Asep Syamsul M. Basic Announcing: Dasar-Dasar Siaran Radio.Bandung: Nuansa. 2009.

Romli, Asep Syamsul M. Manajemen Program \& Teknik Produksi Siaran Radio. Bandung: Nuansa. 2017

Ruslan, Rosady. Metode Penelitian Public Relations dan Komunikasi. Jakarta: PT Rajagrafindo Persada. 2010.

Sugiya, Aritasius. Strategi Transformasi Konvergensi Media. Jakarta: Universitas Indonesia. 2012.

Suharsaputra, Uhar. Metode Penelitian Kuantitatif, Kualitatif, Tindakan. Bandung: Refika Aditama. 2014.

Surahmanto, Heri. Strategi Penyiaran Radio Songgolangit FM Ponorogo Dalam Memberikan Informasi Seputar Ponorogo Pada Program Acara Graha Warta. Skripsi Universitas Muhammadiyah Ponorogo: Ilmu Komunikasi. 2017.

Susilo, Deby Rizky. Pengaruh Konvergensi Media Massa Terhadap Kepuasan Pelanggan Lampungpost.id. Lampung: Universitas Lampung. 2019. 